\title{
REPRESENTAÇÕES DA AFETIVIDADE NA PERSONAGEM NEGRA: AMORES DE BALDO, NO ROMANCE JUBÍABÁ, DE JORGE AMADO.
}

1. Larissa Ribeiro Marques; Licenciatura em Letras com Língua Francesa; Universidade Estadual de Feira de Santana; e-mail: larissarimax@ gmail.com

2. Humberto Luíz Lima de Oliveira; Departamento de Letras e Artes; Universidade Estadual de Feira de Santana; email: humbert_oliveira@uefs.

PALAVRAS-CHAVE: Literatura, racismo, utopias.

RESUMO: Este trabalho pretende ser o resultado parcial do projeto de pesquisa Assim caminha a humanidade? do Individualismo, do Coletivismo e do Comunitário. Revisitando utopias, e busca fazer um estudo da representação da afetividade da personagem negra em narrativas literárias, neste caso em Jubiabá, do escritor brasileiro Jorge Amado, de origem baiana. Publicado em 1933, este romance desperta nossa atenção na medida em que se constitui na primeira narrativa ficcional a trazer uma personagem de etnia negra como herói narrativo, nas primeiras décadas do século XX, ainda com as marcas bem vivas do período escravocrata vivido pela sociedade brasileira.

Apesar do caráter de protagonista dado pelo escritor ao negro Antonio Balduíno, pensamos ser inegável a presença de estereótipos negativos que se revelam na narrativa. De fato, o espaço ficcional do romance será formado tanto pelas imagens do Morro do capa Negro, em Salvador, quando pelas paisagens do Recôncavo baiano, com a presença incontornável do mar.

No que diz respeito às personagens, a narrativa delimita o contraste entre o modo de viver e produzir e amar dos ricos e pobres, num discurso contundente de crítica social, de denúncia das instituições e das injustiças sob as quais vivem a maioria da população pobre e de descendência afro.

O livro Jubiabá é uma ficção literária que retrata a historia do Jovem Antonio Balduino que viveu diversas aventuras durante suas vida nas terras baianas e sofreu os mais diversos tipos de preconceitos que circundam a vida de um jovem negro dentro das suas relações sociais. Este trabalho buscou pontos que caracterizam a identidade afetiva do protagonista no âmbito da identidade regional, mapeando quais lugares são reservados para ele na nesta narrativa literária. 